\title{
Effect of chromium supplementation on glycated hemoglobin and fasting plasma glucose in patients with diabetes mellitus
}

Raynold V Yin and Olivia J Phung*

\begin{abstract}
Aims: Chromium $(\mathrm{Cr})$ is a trace element involved in glucose homeostasis. We aim to evaluate and quantify the effects of $\mathrm{Cr}$ supplementation on A1C and FPG in patients with T2DM.

Materials and methods: A systematic literature search of Pubmed, EMBASE and the Cochrane Library (from database inception to 11/2014) with no language restrictions sought RCTs or cohort studies evaluating Cr supplementation in T2DM vs control and reporting either change in glycated hemoglobin (A1C) or fasting plasma glucose (FPG). Meta-analysis was conducted on each subtype of $\mathrm{Cr}$ supplement separately, and was analyzed by random effects model to yield the weighted mean differences (WMD) and 95\% confidence intervals (Cls). Heterogeneity was assessed by using the $I^{2}$ statistic.

Results: $A$ total of 14 RCTs ( $n=875$ participants, mean age range: 30 to 83 years old, 8 to 24 weeks of follow-up) were identified (Cr chloride: $n=3$ study, Cr picolinate: $n=5$ study, brewer's yeast: $n=4$ study and Cr yeast: $n=3$ study). Compared with placebo, $\mathrm{Cr}$ yeast, brewer's yeast and $\mathrm{Cr}$ picolinate did not show statistically significant effects on A1C. Furthermore, compared to control, $\mathrm{Cr}$ chloride, $\mathrm{Cr}$ yeast and $\mathrm{Cr}$ picolinate showed no effect on FPG, however, brewer's yeast showed a statistically significant decrease in $\mathrm{FPG}-19.23 \mathrm{mg} / \mathrm{dL}\left(95 \% \mathrm{Cl}=-35.30\right.$ to $-3.16, \mathrm{I}^{2}=21 \%$, $\mathrm{n}=137$ ).
\end{abstract}

Conclusions: $\mathrm{Cr}$ supplementation with brewer's yeast may provide marginal benefits in lowering FPG in patients with T2DM compared to placebo however it did not have any effect on A1C.

Keywords: Chromium, Diabetes mellitus, Fasting plasma glucose, Glycated hemoglobin, Meta-analysis, Systematic review

\section{Introduction}

Type 2 diabetes mellitus (T2DM) is the most prevalent form of diabetes worldwide [1,2]. It is characterized by defects in pancreatic insulin secretion or action causing hyperglycemia attributable to disturbances in carbohydrate, fat and lipid metabolism [1]. The worldwide prevalence of T2DM is increasing and more than 366 million people are expected to be affected by the year 2030 [2]. Symptomatic adverse drug events associated with current therapy may affect the patients' adherence and the overall risk-benefit ratio of a drug [3]. Despite the advances in modern medicine, T2DM continues to be a public health concern. In a study conducted by the

\footnotetext{
* Correspondence: ophung@westernu.edu

Western University of Health Sciences, College of Pharmacy, 309 E. Second St, Pomona, CA 91766, USA
}

Medical Expenditure Panel Survey, individuals with diabetes are 1.6 times more likely to use alternative medicine, such as chromium, as compared to individuals without $[4,5]$.

Chromium $(\mathrm{Cr})$ is a common supplement used by many patients with T2DM for the purpose of improving glucose regulation and in 2002, sales of chromium supplements were estimated at $\$ 85$ million [6]. According to the National Institute of Health: Office of Dietary Supplements, an adequate intake of $\mathrm{Cr}$ for men and women is 35 and $25 \mu \mathrm{g} /$ day, resepectively $[7,8]$. Chromium chloride is the naturally occurring trivalent variety of chromium found in common food sources such as: whole grains, broccoli, mushrooms and green beans. In contrast, $\mathrm{Cr}$ picolinate is the synthetic sibling of $\mathrm{Cr}$ chloride. Additional forms of $\mathrm{Cr}$ supplementation may 
also come from $\mathrm{Cr}$ yeast and brewer's yeast. Chromium is an essential micronutrient linked to the regulation of many processes in the human body including glucose homeostasis. Chromium helps to regulate glucose homeostasis by activating insulin receptors through the oligopeptide chromudulin thereby increasing insulin signal transduction and sensitivity [8]. A deficiency in $\mathrm{Cr}$ may result in glucose intolerance, elevated circulating insulin, fasting hyperglycemia, and even impair growth [9].

In recent years, using $\mathrm{Cr}$ for treatment of T2DM has been called into question because of mixed results from published data. There is currently insufficient evidence in the literature to make a definitive conclusion about the effects of $\mathrm{Cr}$ on glucose control. Current trials evaluating $\mathrm{Cr}$ supplementation on glucose control has resulted in conflicting results. The aim of this systematic review and meta-analysis is to assess the effectiveness of $\mathrm{Cr}$ supplementation in lowering A1C and FPG in patients with T2DM.

\section{Materials and methods}

Data source and search strategy

A comprehensive systematic literature search of Pubmed, Embase, and the Cochrane Library was conducted from the inception of each database to November 2014 with no language restrictions applied. The search strategy combined keywords and medical subject headings related to
Cr supplementation and T2DM. A manual search of references from relevant articles was also performed to identify any additional studies. For further details about the search strategy, see Appendix.

Study selection, data abstraction and validity assessment Studies were included in the analysis if they were either RCTs or observational trials in patients with T2DM evaluating $\mathrm{Cr}$ supplementation in any dose or form, and also reported any of the following endpoints: A1C or FPG. Two investigators were responsible for completing study selection, data abstraction and validity assessment for all trials evaluated in this study. Data abstraction was completed by each investigator independently using a standardized data abstraction tool. Each investigator was responsible for obtaining the following information from each trial: author, publication year, funding source, description of study population, inclusion and exclusion criteria, study design, duration of study and intervention details. Validity assessment of RCTs was completed using the Cochrane Risk of Bias Tool [10]. The validity assessment had six domains covering: randomization, allocation concealment, blinding, blinding of outcomes assessment, incomplete data reporting and selective reporting. Each domain was scored as either having a low, unclear, or high risk of bias. Any discrepancies were resolved through discussion.

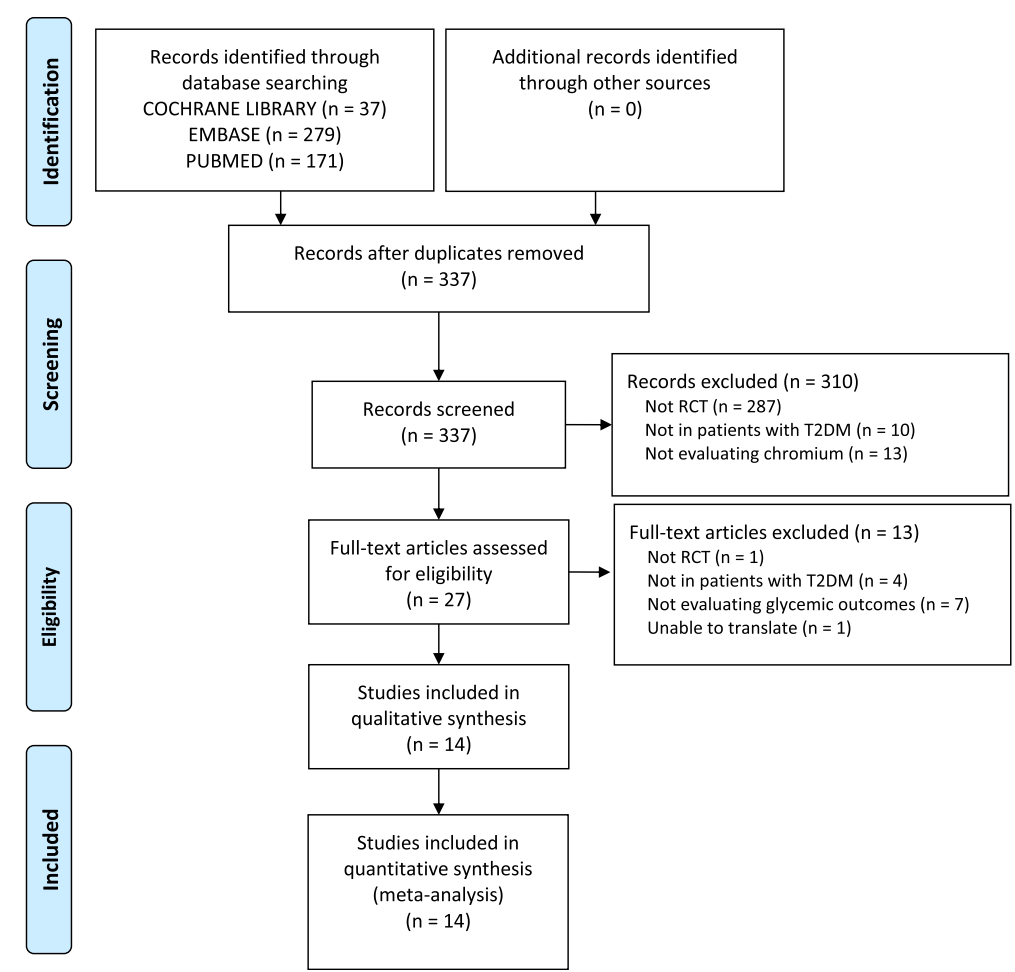

Figure 1 PRISMA diagram. Flowchart depicting when studies were excluded from the study and why. 
Table 1 Baseline study characteristics

\begin{tabular}{|c|c|c|c|c|c|c|c|c|}
\hline $\begin{array}{l}\text { Author, } \\
\text { year, N }\end{array}$ & Inclusion criteria & Follow up & Product evaluated & Dose and frequency & $\begin{array}{l}\text { Age (years), } \\
\text { males }(\%) \\
(\text { mean } \pm \text { SD) }\end{array}$ & $\begin{array}{l}\text { Duration of } \\
\text { DM (years) } \\
\text { (mean } \pm \text { SD) }\end{array}$ & $\begin{array}{l}\text { Baseline A1C } \\
(\%), \text { FBG (mg/dL) } \\
(\mathrm{mean} \pm \text { SD) }\end{array}$ & $\begin{array}{l}\text { Baseline weight } \\
(\mathrm{kg}), \mathrm{BMI}\left(\mathrm{kg} / \mathrm{m}^{2}\right) \\
(\mathrm{mean} \pm \mathrm{SD})\end{array}$ \\
\hline \multirow[t]{2}{*}{$\begin{array}{l}\text { Chen, 2013, } \\
N=66\end{array}$} & \multirow{2}{*}{$\begin{array}{l}\text { 30-75YO, T2DM } \geq 4 \text { months, } \\
\text { stable on OHA x3 months, } \\
\text { FBG } 140-250 \mathrm{mg} / \mathrm{dL} \text {, A1C } \\
7.5-12 \% \text {, BMl } 20-35 \mathrm{~kg} / \mathrm{m}^{2}\end{array}$} & \multirow[t]{2}{*}{16 weeks } & $\begin{array}{l}\text { Chromium chloride } \\
(n=38)\end{array}$ & $200 \mathrm{mcg}, \mathrm{BID}$ & $62 \pm 53,58$ & $N R$ & $8.4 \pm 8.6,171 \pm 314$ & $N R, 28 \pm 26$ \\
\hline & & & Placebo $(n=28)$ & - & $54 \pm 45,75$ & NR & $8.5 \pm 6.88,191 \pm 389$ & $N R, 26 \pm 21$ \\
\hline \multirow[t]{2}{*}{$\begin{array}{l}\text { Jain, 2012, } \\
N=50\end{array}$} & \multirow{2}{*}{$\begin{array}{l}\text { T2DM, 30-55YO, signed } \\
\text { consent, willingness to } \\
\text { participate, not pregnant }\end{array}$} & \multirow[t]{2}{*}{3 months } & $\begin{array}{l}\text { Chromium picolinate } \\
(n=25)\end{array}$ & 400 mcg, unspecified & $51 \pm 10,28$ & $N R$ & $7.5 \pm 1.6,129 \pm 44$ & $104 \pm 32,37 \pm 11$ \\
\hline & & & Placebo $(n=25)$ & - & $49 \pm 10,8$ & $N R$ & $7.84 \pm 1.7,142 \pm 62$ & $100 \pm 28,38 \pm 9$ \\
\hline \multirow[t]{2}{*}{$\begin{array}{l}\text { Król, 2011, } \\
N=40\end{array}$} & \multirow{2}{*}{$\begin{array}{l}\text { T2DM, not pregnant or } \\
\text { breastfeeding, without } \\
\text { vitamin-mineral } \\
\text { supplementation in the } \\
\text { last } 3 \text { months }\end{array}$} & \multirow[t]{2}{*}{8 weeks } & Brewer's yeast $(n=20)$ & $\begin{array}{l}100 \text { mcg, } 2 \text { tablets QAM, } \\
2 \text { tablets in the afternoon, } \\
1 \text { tablet QPM }\end{array}$ & $\begin{array}{l}55 \pm 9 \text { years old } \\
\text { for } N=40,55 \text { for } \\
N=50\end{array}$ & $\begin{array}{l}11.5 \pm 7.8 \\
\text { for } N=40\end{array}$ & $8.09 \pm 2.17,194 \pm 61$ & $N R, 35 \pm 9$ \\
\hline & & & Placebo $(n=20)$ & - & $\begin{array}{l}55 \pm 9 \text { years old } \\
\text { for } N=40,55 \text { for } \\
N=50\end{array}$ & $\begin{array}{l}11.5 \pm 7.8 \\
\text { for } N=40\end{array}$ & $7.95 \pm 80,167 \pm 47$ & $N R, 36 \pm 10$ \\
\hline \multirow[t]{2}{*}{$\begin{array}{l}\text { Sharma, 2011, } \\
N=40\end{array}$} & \multirow{2}{*}{$\begin{array}{l}\text { Not specified, however, } \\
\text { authors noted that patients } \\
\text { who enrolled had T2DM }\end{array}$} & \multirow[t]{2}{*}{3 months } & Brewer's yeast $(n=20)$ & 42 mcg, 3 capsules TID & $\begin{array}{l}35-67 \text { years old } \\
\text { for } N=40, N R\end{array}$ & NR & $9.5 \pm 1.2,198 \pm 30$ & $N R, 25 \pm 9$ \\
\hline & & & Placebo $(n=20)$ & - & $\begin{array}{l}35-67 \text { years old } \\
\text { for } N=40, N R\end{array}$ & $N R$ & $9.30 \pm 0.98,226 \pm 82$ & $N R, 26 \pm 4$ \\
\hline \multirow{2}{*}{$\begin{array}{l}\text { Lai, 2008, } \\
N=20\end{array}$} & \multirow{2}{*}{$\begin{array}{l}<56 \mathrm{YO}, \mathrm{DM} \times 5 \text { years, } \\
\mathrm{FBG}>153 \mathrm{mg} / \mathrm{dL} \\
\mathrm{A} 1 \mathrm{~L}>8.5 \%\end{array}$} & \multirow[t]{2}{*}{6 months } & Chromium yeast $(n=10)$ & 1,000 mcg, unspecified & $53 \pm 2,40$ & NR & $10.2 \pm 0.5,225 \pm 9$ & $N R, 26 \pm 0.9$ \\
\hline & & & Placebo $(n=10)$ & - & $51 \pm 2,50$ & NR & $10.1 \pm 0.4,221 \pm 17$ & $N R, 26 \pm 0.8$ \\
\hline \multirow{2}{*}{$\begin{array}{l}\text { Kleefstra, 2007, } \\
N=57\end{array}$} & \multirow{2}{*}{$\begin{array}{l}\text { A1C } 7-8.5 \% \text {, only on } \mathrm{OHG} \text {, } \\
\text { no change to } \mathrm{TX} \text { in } 3 \\
\text { months, } \mathrm{CrCl}>50 \mathrm{~mL} / \mathrm{min} \text {, } \\
\text { ALT }<90 \text { units } / \mathrm{L}\end{array}$} & \multirow[t]{2}{*}{6 months } & Chromium yeast $(n=29)$ & 100 mcg, 2 tablets BID & $68 \pm 8,62$ & 6 & $6.9 \pm 0.67,157 \pm 41$ & $88 \pm 20,30 \pm 6$ \\
\hline & & & Placebo $(n=28)$ & - & $66 \pm 9,61$ & 4.5 & $7.01 \pm 0.50,144 \pm 32.4$ & $87 \pm 17,30 \pm 6$ \\
\hline \multirow[t]{3}{*}{$\begin{array}{l}\text { Kleefstra, 2006, } \\
N=46\end{array}$} & \multirow{3}{*}{$\begin{array}{l}<75 Y O, A 1 C>8 \% \text {, daily } \\
\text { insulin } \geq 50 \text { units, } \\
\mathrm{CrCl}>50 \mathrm{~mL} / \mathrm{min}\end{array}$} & \multirow[t]{3}{*}{6 months } & $\begin{array}{l}\text { Chromium picolinate } \\
(n=14)\end{array}$ & $250 \mathrm{mcg}, \mathrm{BID}$ & $60 \pm 9,29$ & $13 \pm 5$ & $9.43 \pm 1.09, \mathrm{NR}$ & $N R, 35 \pm 7$ \\
\hline & & & $\begin{array}{l}\text { Chromium picolinate } \\
(n=15)\end{array}$ & $500 \mathrm{mcg}, \mathrm{BID}$ & $59 \pm 6,33$ & $11 \pm 6$ & $9.67 \pm 0.91, N R$ & $N R, 33 \pm 4$ \\
\hline & & & Placebo $(n=17)$ & - & $62 \pm 8,59$ & $18 \pm 8$ & $9.41 \pm 1.01, N R$ & $N R, 34 \pm 4$ \\
\hline \multirow[t]{2}{*}{$\begin{array}{l}\text { Racek, 2006, } \\
N=36\end{array}$} & \multirow[t]{2}{*}{$\begin{array}{l}>18 \mathrm{YO}, \mathrm{T} 2 \mathrm{DM} \text {, agreement } \\
\text { with study protocol }\end{array}$} & \multirow[t]{2}{*}{12 weeks } & $\begin{array}{l}\text { Chromium enriched } \\
\text { yeast }(n=19)\end{array}$ & 100 mcg, 2 tablets BID & 60.8 [37-80], 37 & 3 & $7.18 \pm 1.52,148 \pm 46$ & $N R, 34 \pm 6$ \\
\hline & & & Placebo $(n=17)$ & - & 62 [47-77], 12 & 6 & $6.94 \pm 1.68,141 \pm 43$ & $N R, 35 \pm 9$ \\
\hline \multirow[t]{2}{*}{$\begin{array}{l}\text { Vrtovec, 2005, } \\
N=60\end{array}$} & \multirow{2}{*}{$\begin{array}{l}\text { T2DM, without renal/hepatic } \\
\text { dysfunction, without } \\
\text { CAD/CVD }\end{array}$} & \multirow[t]{2}{*}{3 months } & $\begin{array}{l}\text { Chromium picolinate } \\
(n=30)\end{array}$ & 1,000 mcg, unspecified & $N R, N R$ & NR & $6.9 \pm 1,160 \pm 36$ & $N R, 30 \pm 4$ \\
\hline & & & Placebo $(n=30)$ & - & $N R, N R$ & $N R$ & $7.0 \pm 1.5,164 \pm 43$ & $N R, 31 \pm 5$ \\
\hline \multirow[t]{2}{*}{$\begin{array}{l}\text { Ghosh, 2002, } \\
N=100\end{array}$} & \multirow{2}{*}{$\begin{array}{l}\text { T2DM, glycemic control ×3 } \\
\text { months, not pregnant, no } \\
\text { allergies to chromium } \\
\text { picolinate, no multi-mineral } \\
\text { supplementation }\end{array}$} & \multirow[t]{2}{*}{12 weeks } & $\begin{array}{l}\text { Chromium picolinate } \\
(n=50)\end{array}$ & 200 mcg, BID & $N R, N R$ & $N R$ & $7.2 \pm 2.5,124 \pm 45$ & $N R, N R$ \\
\hline & & & Placebo $(n=50)$ & - & $N R, N R$ & NR & $7.2 \pm 1.9,122 \pm 49$ & $N R, N R$ \\
\hline
\end{tabular}


Table 1 Baseline study characteristics (Continued)

\begin{tabular}{|c|c|c|c|c|c|c|c|c|}
\hline \multirow[t]{3}{*}{$\begin{array}{l}\text { Bahijiri, 2000, } \\
N=141\end{array}$} & \multirow{3}{*}{$\begin{array}{l}\text { T2DM, negative history of } \\
\text { pituitary, thyroid, kidney, or } \\
\text { liver disease, no digestive } \\
\text { problems, no vitamin } \\
\text { supplements }\end{array}$} & \multirow[t]{3}{*}{8 months } & $\begin{array}{l}\text { Chromium chloride } \\
(n=67)\end{array}$ & $200 \mathrm{mcg}$, unspecified & \multirow[t]{3}{*}{$\begin{array}{l}36-68 \text { years old } \\
\text { for } N=141,38 \\
\text { for } N=141\end{array}$} & \multirow[t]{3}{*}{$N R$} & \multirow[t]{3}{*}{$N R, N R$} & \multirow[t]{3}{*}{$N R, 31 \pm 8$} \\
\hline & & & Brewer's yeast $(n=74)$ & $23.2 \mathrm{mcg}$, unspecified & & & & \\
\hline & & & Placebo $(n=69)$ & - & & & & \\
\hline \multirow[t]{3}{*}{$\begin{array}{l}\text { Anderson, 1997, } \\
N=155\end{array}$} & \multirow{3}{*}{$\begin{array}{l}\text { Free of other disease, T2DM, } \\
25-65 \mathrm{YO}, \mathrm{FBG} \text { between } 130 \\
\mathrm{mg} / \mathrm{dL}-230 \mathrm{mg} / \mathrm{dL}, 2 \mathrm{HOGTT} \\
\text { between } 170 \mathrm{mg} / \mathrm{dL}- \\
300 \mathrm{mg} / \mathrm{dL}, \mathrm{A} 1 \mathrm{C} \text { between } \\
8 \%-12 \%\end{array}$} & \multirow[t]{3}{*}{4 months } & $\begin{array}{l}\text { Chromium picolinate } \\
(n=53)\end{array}$ & 100 mcg, BID & $56 \pm 1, N R$ & $8 \pm 1$ & $9.4 \pm 2.18,184 \pm 39$ & $69 \pm 2,25 \pm 0.5$ \\
\hline & & & $\begin{array}{l}\text { Chromium picolinate } \\
(n=52)\end{array}$ & $500 \mathrm{mcg}, \mathrm{BID}$ & $55 \pm 1, N R$ & $5 \pm 0.7$ & $9.4 \pm 2.16,176 \pm 39$ & $68 \pm 1,25 \pm 0.4$ \\
\hline & & & Placebo $(n=50)$ & - & $56 \pm 1, N R$ & $5 \pm 0.7$ & $9.1 \pm 2.12,176 \pm 38$ & $69 \pm 1,25 \pm 0.5$ \\
\hline \multirow[t]{2}{*}{$\begin{array}{l}\text { Abraham, 1992, } \\
N=25\end{array}$} & \multirow{2}{*}{$\begin{array}{l}\text { Authors did not clearly } \\
\text { specify, however, they did } \\
\text { note that patients with T2DM } \\
\text { were enrolled and had } \\
\text { established atherosclerotic } \\
\text { disease }\end{array}$} & \multirow[t]{2}{*}{16 months } & $\begin{array}{l}\text { Chromium chloride } \\
(n=13)\end{array}$ & $250 \mathrm{mcg}$, unspecified & $\mathrm{NR}, \mathrm{NR}$ & NR & $N R, 175 \pm 36$ & $N R, N R$ \\
\hline & & & Placebo $(n=12)$ & - & $N R, N R$ & NR & $N R, 176 \pm 42$ & $N R, N R$ \\
\hline \multirow[t]{2}{*}{$\begin{array}{l}\text { Hunt, } 1985 \\
N=39\end{array}$} & \multirow[t]{2}{*}{$\begin{array}{l}\text { T2DM, BG >140 mg/dL, } \\
\text { A1C > } 8 \%\end{array}$} & \multirow[t]{2}{*}{90 days } & Brewer's yeast $(n=22)$ & 68 mcg/day, BID & $\begin{array}{l}62 \pm 16 \text { years old } \\
\text { for } N=39,73 \text { for } \\
N=79\end{array}$ & NR & $11.1,204$ & $123 \pm 22$ for $N=39, N R$ \\
\hline & & & $\begin{array}{l}\text { Placebo - Torula yeast } \\
(n=17)\end{array}$ & - & $\begin{array}{l}62 \pm 16 \text { years old } \\
\text { for } N=39,73 \text { for } \\
N=9\end{array}$ & NR & 11,186 & $123 \pm 22$ for $N=39, N R$ \\
\hline
\end{tabular}

$T X$ treatment, CAD coronary artery disease, CVD cardiovascular disease. 


\section{Data synthesis and statistical analysis}

To explore and quantify the changes $\mathrm{Cr}$ supplementation has on A1C and FPG, each parameter was treated as a continuous variable. The weighted mean differences (WMDs) and accompanying 95\% confidence intervals (CI) were pooled using a DerSimonian and Laird randomeffects model [11]. Meta-analysis was conducted on each subtype of $\mathrm{Cr}$ supplement separately using StatsDirect software version 2.7.9. A p-value of $<0.05$ was considered statistically significant for all analyses. Moreover, statistical heterogeneity between individual trials was determined using the $\mathrm{I}^{2}$ statistic. Heterogeneity value ranges from 0 to 100 , with 25,50 and $75 \%$ representing low, moderate, and high risk of statistical heterogeneity, respectively. Publication bias was planned using visual inspection of funnel plots to identify the relationship between effect size and sample size and Egger's weighted regression statistic was used to evaluate asymmetry $[12,13]$; however, the small number of RCTs per analysis precluded the ability to statistically analyze this.

\section{Results}

\section{Study characteristics}

Upon screening for inclusion and exclusion of studies, 14 nonduplicate RCTs ( $\mathrm{n}=875$ patients, mean age range: 30 to 83 years old, 8 to 24 weeks of follow-up) met inclusion criteria (Figure 1) [13-27]. No observational studies were found to be eligible for inclusion in this study. Of the 14 unique studies identified, 11 reported results for $\mathrm{A} 1 \mathrm{C}$ and 12 reported results for FPG. Patients in the intervention group received $\mathrm{Cr}$ supplement (dosing range $126 \mathrm{mcg}$ 1,000 mcg daily) in the form of either: $\mathrm{Cr}$ chloride $(\mathrm{n}=3)$ $[17,18,20], \mathrm{Cr}$ picolinate $(\mathrm{n}=5)[16,21,23,24,28], \mathrm{Cr}$ yeast $(\mathrm{n}=3)[26,27,29]$, or brewer's yeast $(\mathrm{n}=4)[15,18,22,25]$. $\mathrm{Cr}$ was dosed one to three times daily (Table 1). Assessment for the Cochrane Risk of Bias tool is presented in Figure 2. The $\mathrm{Cr}$ levels for patients included in this metaanalysis were either not reported or within normal limits.

\section{Quantitative data synthesis}

For each $\mathrm{Cr}$ subtype evaluated, publication bias was either not detected or unobtainable due to few studies.

\section{Cr chloride}

Chromium chloride is the naturally occurring trivalent variety of chromium found in common food sources such as: whole grains, broccoli, mushrooms and green beans. Results from the meta-analysis suggests that $\mathrm{Cr}$ chloride did not have a statistically significant effect on lowering FPG in patients with T2DM when compared to placebo $-6.74 \mathrm{mg} / \mathrm{dL}$ ( $95 \% \mathrm{CI}=-26.64$ to 13.16 , $\mathrm{I}^{2}=31 \%$ ) (Figure 3). Meta-analysis of $\mathrm{Cr}$ chloride on A1C could not be conducted because only one study reported this outcome [20].

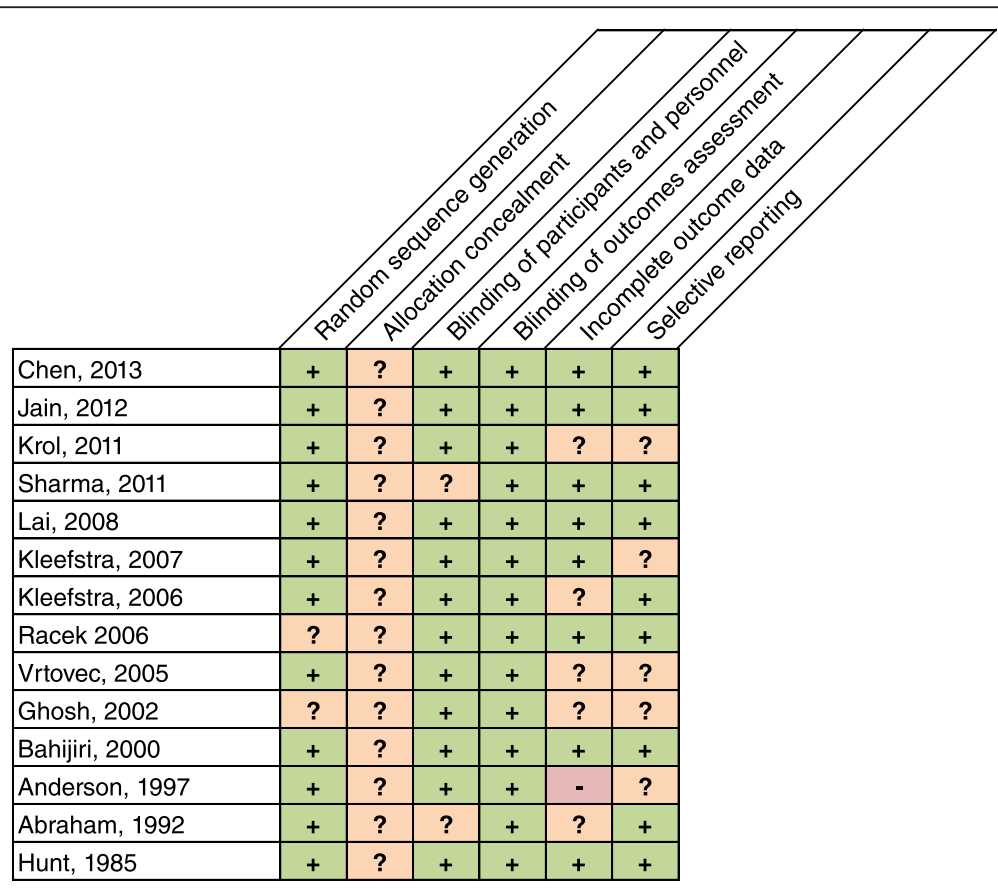

Figure 2 Cochrane risk of bias assessment tool. Six domains are evaluated, random sequence generation, allocation concealment, blinding of participants and personnel, blind of outcomes assessment, incomplete outcome data and selective reporting. - - ? and + represents either a high, unknown or low risk of bias, respectively. 


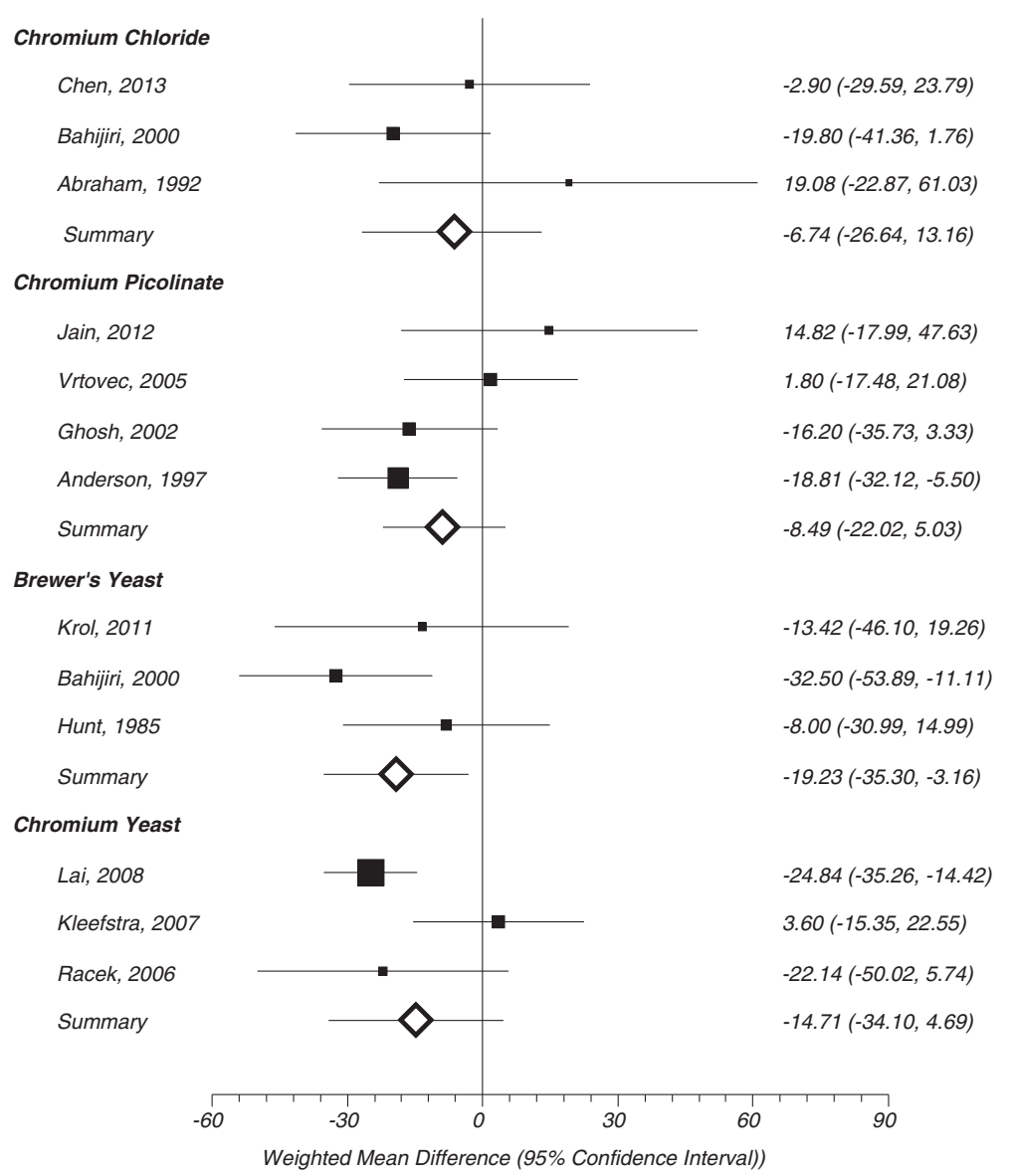

Figure 3 Forest plot depicting results from each subtype of $\mathrm{Cr}$ supplement evaluating the effects of FPG vs. placebo based on year of publication.

\section{Cr picolinate}

$\mathrm{Cr}$ picolinate is the synthetic salt form of $\mathrm{Cr}$ chloride. Picolinic acid may serve to improve chromium absorption. Upon meta-analysis, $\mathrm{Cr}$ picolinate did not show a statistically significant improvement for lowering A1C -0.60\% (95\% CI $=-1.27$ to $0.07, \mathrm{I}^{2}=78 \%, \mathrm{n}=392$ ) (Figure 4 ) or $\mathrm{FPG}-8.49 \mathrm{mg} / \mathrm{dL}\left(95 \% \mathrm{CI}=-22.02\right.$ to $\left.5.03, \mathrm{I}^{2}=48 \%\right)$ (Figure 3 ) in patients with T2DM.

\section{Cr yeast}

An additional form of $\mathrm{Cr}$ supplementation may also come from $\mathrm{Cr}$ yeast. Results from this meta-analysis suggests that $\mathrm{Cr}$ yeast did not have a statistically significant improvement in lowering $\mathrm{A} 1 \mathrm{C} 0.25 \%$ (95\% CI $=-1.07$ to $0.57, \mathrm{I}^{2}=90 \%, \mathrm{n}=113$ ) (Figure 4 ) or $\mathrm{FPG}-14.71 \mathrm{mg} / \mathrm{dL}$ $\left(95 \% \mathrm{CI}=-34.10\right.$ to $\left.4.69, \mathrm{I}^{2}=70 \%\right)$ (Figure 3 ).

\section{Brewer's yeast}

Trivalent $\mathrm{Cr}$ is considered the biologically active form of $\mathrm{Cr}$ and it was originally discovered in brewer's yeast [30].
Brewer's yeast did not have a statistically significant effect on lowering $\mathrm{A} 1 \mathrm{C}$ in patients with $\mathrm{T} 2 \mathrm{D}-0.71 \%$ (95\% CI $=-2.29$ to $0.87, \mathrm{I}^{2}=87 \%, \mathrm{n}=99$ ) (Figure 4 ). However, brewer's yeast demonstrated a statistically significant decrease in FPG $-19.23 \mathrm{mg} / \mathrm{dL}$ (95\% CI = -35.30 to $-3.16, \mathrm{I}^{2}=21 \%$ ) (Figure 3 ) in patients with T2DM compared to placebo.

\section{Discussion}

Results from this study suggest that $\mathrm{Cr}$ does not have a statistically significant effect on A1C when administered in patients with T2DM. Furthermore, $\mathrm{Cr}$ chloride, $\mathrm{Cr}$ yeast or $\mathrm{Cr}$ picolinate did not improve FPG in patients with T2DM. However, brewer's yeast had a statistically significant reduction in FPG when compared to placebo.

The limitations of this meta-analysis should be considered when interpreting these results. The high level of heterogeneity may be a limiting factor of this study. Visual inspection of funnel plots indicated the potential for publication bias and a lack of symmetry to some 


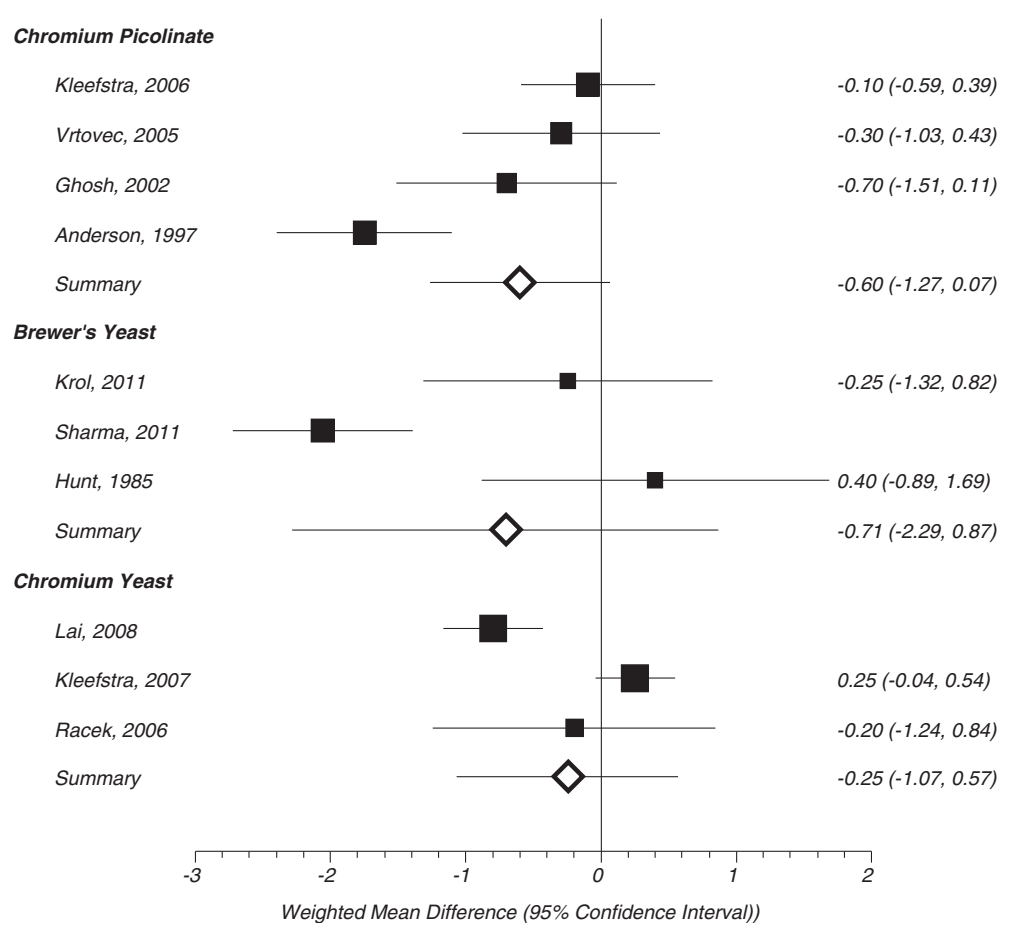

Figure 4 Forest plot depicting results from each subtype of $\mathrm{Cr}$ supplement evaluating the effects of A1C vs. placebo based on year of publication. Note: The squares represent the pooled results of that study in addition to all studies preceding it. Error bars represent $95 \% \mathrm{Cls}$ and the diamond represents the overall pooled results. The solid vertical line extending upward from 0 is the null value.

extent. Variables such as: age, gender, frequency of dose, formulation and duration of the study may have contributed to the high heterogeneity of the study. Although publication bias could not be statistically assessed; the comprehensive search strategy employed may have prevented the exclusion of relevant evidence. Furthermore, the trials included in this meta-analysis only included published trials.

Many factors may have contributed to the polar results obtained between Abraham et al. [17] and Bahijiri et al. [19] when exploring the effects of $\mathrm{Cr}$ chloride on FPG when compared to placebo (Figure 3). Changes in the standard of care for patients with T2DM between 1992 when Abraham et al. [17] was published and 2000 when Bahijiri et al. [19] was published may have contributed to the inconsistent results between the two studies. Furthermore, the patient population studied in Abraham et al. [17] recruited patients who were at high risk (i.e. previous myocardial infarction, moderate to severe intermittent claudication) compared to patients recruited by Bahijiri et al. [19]. Furthermore, Bahijiri et al. [19] only recruited patients who were either of Saudi origin or Arabs compared to Abraham et al. [17] who did not exclusively specify ethnic background as a factor for enrollment into the study. Consequently, this may have introduced variations (i.e. diet and lifestyle differences) in the patient population, ultimately contributing to the polar results between the two studies.

Future research evaluating the effects of $\mathrm{Cr}$ supplementation should attempt to identify the subgroup of patients in which $\mathrm{Cr}$ therapy may be beneficial (i.e. T2DM patients with Cr deficiency). Furthermore, a large sample size with adequate power and sufficient duration of therapy may be desired for reliable and trustworthy results. Finally, future research may consider properly controlling for concomitant antidiabetic medications to truly isolate the effect size of $\mathrm{Cr}$ supplementation in patients with T2DM.

Although it has been suggested that $\mathrm{Cr}$ supplementation promotes glucose control, there is insufficient evidence in the literature to make a definitive conclusion about the effects of $\mathrm{Cr}$ in patients with T2DM. Current trials evaluating $\mathrm{Cr}$ on glycemic control has led to conflicting results. Results from a 3 month randomized single-blinded study evaluating adults with T2DM (35-67 years old) suggested that $\mathrm{Cr}$ supplementation (42 $\mathrm{mcg} /$ daily) significantly reduced both A1C $(9.51 \pm 0.26 \%$ to $6.68 \pm 0.28 \%$; $<0.001)$ and FPG $(197.65 \pm 8.68 \mathrm{mg} / \mathrm{dL}$ to $103.68 \pm 6.64 \mathrm{mg} / \mathrm{dL}$; $\mathrm{p}<0.001$ ) [14]. However, results from a double-blinded $\mathrm{RCT}$ evaluating $\mathrm{Cr}$ as adjuvant therapy in patients with 
T2DM reported no statistically significant differences between the intervention ( $\mathrm{Cr} 400 \mathrm{mcg} /$ daily) and placebo group for A1C after 6 month [16]. Moreover, results from a double-blinded, placebo-controlled cross-over trial evaluating 30 patients with T2DM also reported no difference between control and $\mathrm{Cr}$ treated $(200 \mathrm{mcg} /$ daily) subjects in glucose control (A1C, FPG) [29].

In conclusion, $\mathrm{Cr}$ supplementation with brewer's yeast may provide marginal benefits in lowering FPG in patients with T2DM compared to placebo control however $\mathrm{Cr}$ supplement as other formulations did not have any effect on A1C or FPG. Consequently, it would be premature to recommend $\mathrm{Cr}$ supplementation as part of the standard of care in patients with T2DM. Additional research with large sample sizes and well-designed RCTs are required to further understand which patient population would benefit the most from $\mathrm{Cr}$ supplement.

\section{Appendix}

Search Strategy

PubMed

(“"chromium" [Mesh] OR "chromium" [all fields]) AND ("diabetes mellitus, type 2" [Mesh] OR " type 2 diabetes" [all fields] OR "type ii diabetes" [all fields] OR "t2dm" [all fields] OR "tiidm" [all fields] OR "NIDDM" [all fields] OR "non insulin dependent diabetes" [all fields] OR "type 2 dm" [all fields]) AND ("humans" [mesh]))

Cochrane library

((“chromium" OR "chromium”) AND ("diabetes mellitus, type 2" OR "type 2 diabetes" OR "type ii diabetes" OR "t2dm" OR "tiidm" OR "NIDDM" OR "non insulin dependent diabetes" OR "type $2 \mathrm{dm}$ ") AND ("humans"))

Embase

(('chromium'/exp OR 'chromium':ti,ab) AND ('diabetes mellitus, type 2'/exp OR ' type 2 diabetes':ti,ab OR 'type ii diabetes':ti,ab OR 't2dm' :ti,ab OR 'tiidm':ti,ab OR 'NIDDM':ti,ab OR 'non insulin dependent diabetes' :ti,ab OR 'type 2 dm':ti,ab) AND ('humans'/exp))

\section{Competing interests}

The authors declare that they have no competing interests.

\section{Authors' contributions}

RVY cobtributed to the search strategy, title and abstract review, data extraction, assessment of risk of bias for included trials, conducted statistical analysis, and drafted the manuscript. OJP contributed to the search strategy, title and abstract review, data extraction, assessment of risk of bias for included trials, analyzed the statistical analysis, and critically reviewed the manuscript. Both authors read and approved the final manuscript.

\section{Received: 27 August 2014 Accepted: 12 January 2015}

Published: 13 February 2015

\section{References}

1. Yeghiazaryan K, Schild HH, Golubnitschaja O. Chromium-picolinate therapy in diabetes care: individual outcomes require new guidelines and navigation by predictive diagnostics. Infect Disord Drug Targets. 2012;12(5):332-9.
2. Wild S, Roglic G, Green A, Sicree R, King H. Global prevalence of diabetes: estimates for the year 2000 and projections for 2030. Diabetes Care. 2004;27:1047-53

3. Hakobyan L, Haaijer-Ruskamp FM, de Zeeuw D, Dobre D, Denig P. A review of methods used in assessing non-serious adverse drug events in observational studies among type 2 diabetes mellitus patients. Health Qual Life Outcomes. 2011;9:83. doi:10.1186/1477-7525-9-83.

4. Yeh GY, Eisenberg DM, Davis RB, Phillips RS. Use of complementary and alternative medicine among persons with diabetes mellitus: results of a national survey. Am J Public Health. 2002;92(10):48-52.

5. Egede $L E, Y e X$, Zheng D, Silverstein MD. The prevalence and pattern of complementary and alternative medicine use in individuals with diabetes. Diabetes Care. 2002;25(2):324-9.

6. Nutrition Business Journal. NBJ's Supplement Business Report 2003. San Diego, CA: Penton Media Inc; 2003.

7. Rabinovitz H, Friedensohn A, Leibovitz A, Gabay G, Rocas C, Habot B. Effect of chromium supplementation on blood glucose and lipid levels in type 2 diabetes mellitus elderly patients. Int J Vitam Nutr Res. 2004;74(3):178-82.

8. National Institute of Health: Office of Dietary Supplements. Chromium: Dietary supplement fact sheet. 2013 [ONLINE] Available at: http://ods.od.nih. gov/factsheets/Chromium-HealthProfessional/. [Accessed 09 February 15].

9. Vincent JB. Elucidating a biological role for chromium at a molecular level. Acc Chem Res. 2000;33(7):503-10.

10. Lee NA, Reasner CA. Beneficial effect of chromium supplementation on serum triglyceride levels in NIDDM. Diabetes Care. 1994;17(12):1449-52.

11. DerSimonian R, Laird N. Meta-analysis in clinical trials. Control Clin Trials. 1986;7(3):177-88.

12. Higgins JP, Altman DG, Gøtzsche PC, Juni P, Moher D, Oxman AD, et al. Cochrane Bias Methods Group; Cochrane Statistical Methods Group. The Cochrane Collaboration's tool for assessing risk of bias in randomised trials. BMJ. 2011;343:d5928.

13. Egger M, Davey Smith G, Schneider M, Minder C. Bias in meta-analysis detected by a simple, graphical test. BMJ. 1997;315(7109):629-34.

14. Wallach S. Clinical and biochemical aspects of chromium deficiency. J Am College Nutr. 1985:4:107-20.

15. Sharma S, Agrawal RP, Choudhary M, Jain S, Goyal S, Agarwal V. Beneficial effect of chromium supplementation on glucose, $\mathrm{HbA1C}$ and lipid variables in individuals with newly onset type-2 diabetes. J Trace Elem Med Biol 2011;25(3):149-53. doi:10.1016/j.jtemb.2011.03.003. Epub 2011 May 12.

16. Anderson RA, Cheng N, Bryden NA, Polansky MM, Cheng N, Chi J, et al. Elevated intakes of supplemental chromium improve glucose and insulin variables in individuals with type 2 diabetes. Diabetes. 1997;46(11):1786-91.

17. Abraham AS, Brooks BA, Eylath U. The effects of chromium supplementation on serum glucose and lipids in patients with and without non-insulindependent diabetes. Metabolism. 1992;41(7):768-71.

18. Bahijiri SM, Mira SA, Mufti AM, Ajabnoor MA. The effects of inorganic chromium and brewer's yeast supplementation on glucose tolerance, serum lipids and drug dosage in individuals with type 2 diabetes. Saudi Med J. 2000;21(9):831-7.

19. Bahijri SM, Mufti AM. Beneficial effects of chromium in people with type 2 diabetes, and urinary chromium response to glucose load as a possible indicator of status. Biol Trace Elem Res. 2002;85(2):97-109.

20. Chen YL, Lin JD, Hsia TL, Mao FC, Hsu CH, Pei D. The effect of chromium on inflammatory markers, 1 st and 2nd phase insulin secretion in type 2 diabetes. Eur J Nutr. 2014;53(1):127-33.

21. Ghosh D, Bhattacharya B, Mukherjee B, Manna B, Sinha M, Chowdhury J, et al. Role of chromium supplementation in Indians with type 2 diabetes mellitus. J Nutr Biochem. 2002;13(11):690-7.

22. Hunt AE, Allen KGD, Smith BA. Effect of chromium supplementation on hair chromium concentration and diabetic status. Nutr Res. 1985;5(2):131-40.

23. Jain SK, Kahlon G, Morehead L, Dhawan R, Lieblong B, Stapleton T, et al. Effect of chromium dinicocysteinate supplementation on circulating levels of insulin, TNF-a, oxidative stress, and insulin resistance in type 2 diabetic subjects: randomized, double-blind, placebo-controlled study. Mol Nutr Food Res. 2012;56(8):1333-41. doi:10.1002/mnfr.201100719. Epub 2012 Jun 6.

24. Kleefstra N, Houweling ST, Jansman FG, Groenier KH, Gans RO, Meyboom-de Jong B, et al. Chromium treatment has no effect in patients with poorly controlled, insulin-treated type 2 diabetes in an obese Western population: a randomized, double-blind, placebo-controlled trial. Diabetes Care. 2006;29(3):521-5. 
25. Król E, Krejpcio Z, Byks H, Bogdański P, Pupek-Musialik D. Effects of chromium brewer's yeast supplementation on body mass, blood carbohydrates, and lipids and minerals in type 2 diabetic patients. Biol Trace Elem Res. 2011;143(2):726-37. doi:10.1007/s12011-010-8917-5. Epub 2010 Dec 18

26. Lai MH. Antioxidant effects and insulin resistance improvement of chromium combined with vitamin $\mathrm{C}$ and e supplementation for type 2 diabetes mellitus. J Clin Biochem Nutr. 2008;43(3):191-8. doi:10.3164/jcbn.2008064. Epub 2008 Oct 31.

27. Racek J, Trefil L, Rajdl D, Mudrová V, Hunter D, Senft V. Influence of chromium-enriched yeast on blood glucose and insulin variables, blood lipids, and markers of oxidative stress in subjects with type 2 diabetes mellitus. Biol Trace Elem Res. 2006;109(3):215-30.

28. Vrtovec M, Vrtovec B, Briski A, Kocijancic A, Anderson RA, Radovancevic B. Chromium supplementation shortens QTc interval duration in patients with type 2 diabetes mellitus. Am Heart J. 2005;149(4):632-6.

29. Kleefstra N, Houweling ST, Bakker SJ, Verhoeven S, Gans RO, Meyboom-de Jong B, et al. Chromium treatment has no effect in patients with type 2 diabetes in a Western population: a randomized, double-blind, placebo-controlled trial. Diabetes Care. 2007;30(5):1092-6. Epub 2007 Feb 15.

30. Schwarz K, Mertz W. Chromium(III) and the glucose tolerance factor. Arch Biochem Biophys. 1959;85:292-5.

\section{Submit your next manuscript to BioMed Central and take full advantage of:}

- Convenient online submission

- Thorough peer review

- No space constraints or color figure charges

- Immediate publication on acceptance

- Inclusion in PubMed, CAS, Scopus and Google Scholar

- Research which is freely available for redistribution 